\title{
PERAN PROGRAM PENGEMBANGAN USAHA AGRIBISNIS PERDESAAN (PUAP) TERHADAP KESEJAHTERAAN PETANI DI DESA POLAGAN, KECAMATAN GALIS, KABUPATEN PAMEKASAN
}

\author{
Siti Ienas Maulidia ${ }^{1}$, Herry Yulistiyono ${ }^{2}$ \\ ${ }^{1,2}$ Fakultas Ekonomi dan Bisnis, Universitas Trunojoyo Madura, Madura, Indonesia \\ Email Korespondensi: msitiienas@gmail.com
}

\begin{abstract}
The purpose of the study was to analyze the role of the Rural Agribusiness Development Program (PUAP) on the welfare of farmers in Polagan Village, Galis District, Pamekasan Regency. The research method used is descriptive qualitative. Data collection methods using interviews, observation, and documentation. Descriptive analysis model analysis technique with data validity test is done by using triangulation of data sources. The results showed that the implementation of the Agribusiness Business Development program in Polagan Village, was good because the distribution process to farmers was in accordance with procedures so that farmers could be used for capital to develop farming. The level of welfare of farmers in Polagan Village as a whole is still low. the role of the Rural Agribusiness Development Program (PUAP) on the welfare of farmers in Polagan Village, Galis District, Pamekasan Regency has not been maximized in terms of targets, techniques, and objectives. Recommendations are that the PUAP program should not only be in the form of agricultural capital loans but through other new innovations. Like the provision of subsidized fertilizer.
\end{abstract}

Keywords: PUAP, Welfare of Farmers, Gapoktan

Abstrak: Tujuan penelitian ini untuk menganalisis peran Program Pengembangan Usaha Agribisnis Perdesaan (PUAP) terhadap kesejahteraan petani di Desa Polagan, Kecamatan Galis, Kabupaten Pamekasan. Metode penelitian yang digunakan adalah kualtiatif deskriptif. Metode pengumpulan data menggunakan wawancara, observasi, dan dokumentasi. Teknik analisis model analisis deskriptif dengan uji keabsahan data dilakukan dengan menggunakan triangulasi sumber data. Hasil penelitian menunjukkan bahwa pelaksanaan program Pengembangan Usaha Agribisnis di Desa Polagan, sudah baik karena proses penyalurannya kepada petani sudah sesuai prosedur sehingga dapat dimanfaatkan petani untuk modal mengembangkan usaha tani. Tingkat kesejahteraan petani di Desa Polagan, secara keseluruhan masih rendah. Peran Program Pengembangan Usaha Agribisnis Perdesaan (PUAP) terhadap kesejahteraan petani di Desa Polagan, Kecamatan Galis, Kabupaten Pamekasan belum maksimal dari segi sasaran, teknik, dan tujuan. Rekomendasi sebaiknya program PUAP tidak hanya berupa dana pinjaman modal pertanian saja akan tetapi melalui inovasi baru lainnya. Seperti halnya penyediaan pupuk bersubsidi

Kata Kunci: PUAP, Kesejahteraan Petani, Gapoktan 


\section{PENDAHULUAN}

Indonesia kaya dengan sumber daya alam karena merupakan negara agraris, namun hal tersebut masih belum mampu mengentaskan kemiskinan utamanya di daerah perdesaan. Jumlah penduduk miskin di perdesaan pada Maret tahun 2019 sejumlah 15,15 juta orang sedangkan di perkotaan sejumlah 9,99 juta orang (BPS, 2019). Penyumbang kemiskinan terbesar di daerah perdesaan ialah sektor pertanian dimana mayoritas masyarakat di perdesaan bekerja pada sektor ini dan banyak pekerja yang hidup di bawah garis kemiskinan.

Keberhasilan pembangunan di negara berkembang, seperti Indonesia, dapat dilihat dari perkembangan di wilayah perdesaan sendiri. Bila mayoritas penduduk di perdesaan bisa melakukan mobilitas sosial-ekonomi (pembangunan), maka dapat disimpulkan pembangunan di negara berkembang telah menjangkau sebagian warga negaranya, demikian sebaliknya (Yustika, 2013). Wilayah perdesaan di negara berkembang biasanya dideskripsikan sebagai tempat bagi orang-orang bekerja di sektor pertanian (70\% dari 20,65 juta jiwa), dimana masyarakat petani mencukupi hidup sendiri (swasembada) (Kementerian Pertanian, 2010).

Salah satu persoalan paling rumit di wilayah perdesaan adalah penyediaan modal. Bahkan, keterbatasan akses terhadap modal (kredit) diidentifikasi sebagai salah satu faktor penyebab kemiskinan. Ditambah lagi, fasilitasi bantuan modal yang diluncurkan pemerintah belum sepenuhnya dapat dinikmati oleh petani. Hal ini disebabkan karena lembaga permodalan formal yang ditunjuk untuk menyalurkannya dirasakan tidak sepenuhnya berpihak kepada petani, bunga yang terlalu tinggi, jaminan persayaratan yang tidak bisa dipenuhi petani, proses pencairan yang memakan waktu sangat lama, birokrasi yang bertele-tele, dan pelayanan yang tidak ramah. Akibat keterbatasan dana dan persyaratan kredit yang memberatkan bagi sebagian petani, sehingga tidak seluruh petani bisa mendapatkan kredit dari program pemerintah tersebut. Petani yang tidak memeroleh kredit, mengandalkan sumber pembiayaan produksi dari modal pinjaman ke tetangga atau tengkulak/rentenir dengan bunga yang lebih tinggi. Akibatnya akan merugikan petani karena memeroleh keuntungan yang lebih kecil (Yustika, 2013).

Berangkat dari permasalahan penyebab ketidakberdayaan masyarakat dalam pengolahan sektor pertanian maka pemerintah berupaya untuk menanganinya melalui berbagai program-program pembangunan yang berbasis pemberdayaan perdesaan, salah satunya adalah program dalam bentuk bantuan langsung masyarakat (BLM) yang disebut Program Pengembangan Usaha Agribisnis Perdesaan (PUAP).

Program PUAP yang merupakan program dari Kementerian Pertanian untuk mengatasi kemiskinan dan menciptakan lapangan kerja, serta mengurangi kesenjangan pembangunan yang ada antar wilayah pusat dengan daerah serta kesenjangan antar subsektor yang ada. Faktanya, tidak semua masyarakat yang mendapatkan bantuan PUAP dapat keluar dari jeratan kemiskinan.

Hasil studi pendahuluan dilakukan di Desa Polagan, Kecamatan Galis, Kabupaten Pamekasan. Secara graografi Desa Polagan merupakan salah satu desa di Kecamatan Galis yang sangat berpotensi dalam mengembangkan usahatani dilihat dari luas lahan terbesar dari sebelas desa yang ada di Kecamatan Galis, yaitu lahan pertanian sebesar 
425.00 Ha dari total lahan pertanian 1,578.00 Ha. Luas lahan pertanian sawah juga terbesar dibandingkan desa yang lain yaitu 229.00 Ha (Kecamatan Galis Dalam Angka 2019). Hasil wawancara menunjukkan bahwa PUAP itu dananya terbatas, jadi tidak semuanya dapat memenuhi modal usaha petani khususnya di anggota. Tapi untuk merangsang, contohnya satu kelompok tani jumlahnya 50 orang, dan kelompok tani tersebut mendapat 10 juta jika dibagi 50 orang hanya sedikit (Hasil Wawancara, Ketua Gapoktan “Arjuna”, 13 November 2019). Pelaksanaan PUAP di Kelompok Tani "Arjuna" ini beberapa ada yang berhasil dan beberapa ada yang gagal. Kegagalan ini menyebabkan petani tidak mendapatkan keuntungan dan bahkan harus mengembalikan modal awal. Hal ini menimbulkan persoalan besar mengenai peran PUAP di Kelompok Tani "Arjuna" ini apakah mampu meningkatkan kesejahteraan petani atau bahkan malah menambah beban petani apabila ada kegagalan.

Fakta di atas menunjukkan bahwa ada kesenjangan antara tujuan Program PUAP dengan tingkat kesejahteraan masyarakat, khususnya para petani yang tergabung dalam anggota Poktan. Hubungan Program PUAP dengan kesejahteraan anggota kelompok tani sesuai hasil penelitian sebelumnya yang dilakukan Darwis (2014) menyatakan bahwa pemberdayaan yang telah dilakukan oleh dinas pertanian melalui program PUAP berdampak pada kesejahteraan anggota kelompok tani Desa Tanjung Tebat Kecamatan Bunga Mas Bengkulu Selatan. Hasil penelitian Hermawan dan Hendayana (2015) menemukan peran BLM PUAP di Kabupaten Kolaka Provinsi Sulawesi Tenggara mampu meningkatkan produktivitas, nilai tambah, daya saing dan ekspor produk pertanian, bahkan pada kegiatan usaha tani yang dilakukan petani mampu memberikan pendapatan yang lebih menguntungkan. Penelitian Suandi, dkk. (2012) menemukan bahwa program PUAP melalui manajemen sumberdaya Gapoktan berpengaruh positif sangat nyata terhadap peningkatan kesejahteraan petani Desa Tunas Mudo, Pematang Pulai, dan Desa Berembang Kecamatan Sekernan Kabupaten Muaro Jambi. Hal ini mengindikasikan bahwa program PUAP sangat berperan terhadap peningkatan kesejahteraan petani namun perlu dikelola secara intensif dan profesional dengan berbasis sumberdaya lokal.

Berdasarkan uraian di atas, maka penelitian ini bertujuan untuk: (1) mengetahui Pelaksanaan Program Pengembangan Usaha Agribisnis Perdesaan (PUAP) di Desa Polagan, Kecamatan Galis, Kabupaten Pamekasan, (2) mengetahui tingkat kesejahteraan petani di Desa Polagan, Kecamatan Galis, Kabupaten Pamekasan, dan (3) menganalisis peran Program Pengembangan Usaha Agribisnis Perdesaan (PUAP) terhadap kesejahteraan petani di Desa Polagan, Kecamatan Galis, Kabupaten Pamekasan.

\section{TINJAUAN PUSTAKA}

\subsection{Teori Pembangunan}

Teori Pembangunan Model Rostow (1960) mengatakan bahwa negara-negara berkembang yang ingin maju harus melalui tahap-tahap pembangunan mulai dari The traditional society atau tahap masyarakat tradisional, the preconditions for take off atau tahap prakondisi menuju tinggal landas, sampai pada take off atau tahap tinggal landas. 
Todaro dan Smith (2003) yang dikutip dalam Sumodiningrat (2001) mendefinisikan pembangunan sebagai proses memperbaiki kualitas kehidupan manusia, yakni (1) menaikkan tingkat kehidupan masyarakat, seperti pendapatan dan konsumsi pangan, kesehatan, pendidikan, dan sebagainya melalui pertumbuhan ekonomi yang sesuai; (2) menciptakan kondisi yang kondusif bagi pertumbuhan harga diri masyarakat melalui pemantapan sistem dan institusi, sosial, politik dan ekonomi yang mengutamakan rasa hormat dan martabat manusia; dan (3) meningkatkan kebebasan masyarakat dengan memperluas kisaran pilihan barang dan jasa.

\subsection{Pembangunan Desa}

Pengertian dari pembangunan desa menurut Undang-Undang Nomor 6 Tahun 2014 adalah upaya peningkatan kualitas hidup dan kehidupan untuk sebesar-besarnya kesejahteraan masyarakat Desa. Berdasarkan definisi di atas, dapat disimpulkan bahwa pembangunan desa adalah segala upaya yang dilakukan untuk mewujudkan kehidupan masyarakat dari baik dari sisi kehidupan, kesejahteraan, maupun kualitas.

Tujuan diadakannya pembangunan desa selain untuk meningkatkan taraf hidup masyarakat juga sebagai pemanfaatan potensi yang dimiliki baik dari sumber daya alam maupun sumber daya manusia secara optimal (Prastiwi, 2010).

\subsection{Pemberdayaan Masyarakat}

Prijono \& Pranarka (1996:77) menyatakan bahwa pemberdayaan mengandung dua arti. Pengertian yang pertama adalah to give power or authority, pengertian kedua to give ability to or enable. Pemaknaan pengertian pertama meliputi memberikan kekuasaan, mengalihkan kekuatan atau mendelegasikan otoritas kepada pihak yang kurang/ belum berdaya. Di sisi lain pemaknaan pengertian kedua adalah memberikan kemampuan atau keberdayaan serta memberikan peluang kepada pihak lain untuk melakukan sesuatu.

Berkenaan dengan pemaknaan konsep pemberdayaan masyarakat, Tri Winarni mengungkapkan bahwa inti dari pemberdayaan adalah meliputi tiga hal yaitu pengembangan, (enabling), memperkuat potensi atau daya (empowering), terciptanya kemandirian (Tri, 1998: 75).

Konsep utama yang terkandung dalam pemberdayaan adalah bagaimana memberikan kesempatan yang luas bagi masyarakat untuk menentukan sendiri arah kehidupan dalam komunitasnya. Pemberdayaan memberikan tekanan pada otonom pengambilan keputusan dari suatu kelompok masyarakat. Penerapan aspek demokrasi dan partisipasi dengan titik fokus pada lokalitas akan menjadi landasan bagi upaya penguatan potensi lokal. Pemberdayaan masyarakat juga difokuskan pada penguatan individual anggota masyarakat beserta pranata-pranatanya. Pendekatan utama dalam konsep pemberdayaan ini adalah menempatkan masyarakat tidak sekedar sebagai obyek melainkan juga sebagai subyek.Konteks pemberdayaan, sebenarnya terkandung unsur partisipasi yaitu bagaimana masyarakat dilibatkan dalam proses pembangunan, dan hak untuk menikmati hasil pembangunan. Pemberdayaan mementingkan adanya pengakuan subyek akan kemampuan atau daya (power) yang dimiliki obyek. Secara 
garis besar, proses ini melihat pentingnya proses ini melihat pentingnya mengalihfungsikan individu yang tadinya obyek menjadi subyek (Suparjan dan Hempri, 2003: 44).

Menurut Aziz, dkk (2005:170) pemberdayaan masyarakat merupakan upaya yang bertujuan untuk menumbuhkan sikap kemandirian masyarakat melalui pencapaian potensi kemampuan yang dimiliki oleh setiap masyarakat. Berdasarkan definisi di atas, dapat disimpulkan bahwa pemberdayaan masyarakat merupakan pelaksanaan yang dilakukan oleh fasilitator terhadap sekolompok masyarakat melalui pengembangan potensi yang dimiliki guna meningkatkan kesejahteraan masyarakat tersebut.

Tujuan dari adanya pemberdayaan masyarakat yaitu untuk menjadikan masyarakat bersikap mandiri sehingga dapat meningkatkan kesejahteraan hidup dalam keluarganya serta dapat mengoptimalkan potensi yang dimilikinya (Widjajanti, 2011).

\subsection{Teori Transformasi Struktural}

Transformasi struktural didefinisikan sebagai perubahan struktur ekonomi dari sektor tradisional yang memiliki produktivitas rendah menuju sektor ekonomi dengan produktivitas tinggi. Artinya, transformasi struktural perekonomian dengan sendirinya akan menjadi suatu kenyataan dan perekonomian itu pun pada akhirnya pasti beralih dari perekonomian pertanian tradisional yang berpusat di pedesaan menjadi sebuah perekonomian industri modern yang berorientasi kepada pola kehidupan perkotaan (Romli et al. 2016).

Teori Transformasi Struktural dalam hal ini dikemukakan oleh Hollis B. Chenery melalui analisis teori Pattern of Development menjelaskan perubahan struktur dalam tahapan proses perubahan ekonomi dari negara berkembang yang mengalami transformasi dari pertanian tradisional beralih ke sektor industri sebagai mesin utama pertumbuhan ekonomi. Peningkatan peran sektor industri dalam perekonomian sejalan dengan peningkatan pendapatan perkapita yang berhubungan sangat erat dengan akumulasi capital dan peningkatan sumber daya (Human Capital) (Romli et al. 2016).

Chenery dalam Tambunan (2013), mengatakan bahwa pada umumnya transformasi yang terjadi di negara sedang berkembang adalah transformasi dari sektor pertanian ke sektor industri. Perubahan struktur atau transformasi ekonomi dari tradisional menjadi modern, yang secara umum didefinisikan sebagai suatu perubahan dalam ekonomi yang berkaitan dengan komposisi penyerapan tenaga kerja, produksi, perdagangan, dan faktor-faktor lain yang diperlukan secara terus-menerus untuk meningkatkan pendapatan dan kesejahteraan sosial melalui peningkatan pendapatan perkapita.

\subsection{Pengembangan Usaha Agribisnis Pedesaan (PUAP)}

Pengembangan Usaha Agribisnis Pedesaan (PUAP) merupakan bentuk fasilitasi bantuan modal usaha bagi petani anggota, baik petani pemilik, petani penggarap, buruh tani maupun rumah tangga tani yang dikoordinasikan oleh Gabungan Kelompok Tani (Gapoktan). Gapoktan merupakan kelembagaan tani pelaksana PUAP 
untuk penyaluran bantuan modal usaha bagi anggota. Untuk mencapai hasil yang maksimal dalam pelaksanaan PUAP, Gapoktan didampingi oleh Tenaga Pendamping PUAP (Penyuluh dan Penyelia Mitra Tani) (Dirjen Prasarana dan Sarana Pertanian, 2015).

PUAP bertujuan untuk: 1) mengurangi kemiskinan dan pengangguran melalui penumbuhan dan pengembangan kegiatan usaha agribisnis di perdesaan sesuai dengan potensi wilayah; 2) meningkatkan kemampuan dan pengetahuan pelaku usaha agribisnis, pengurus Gapoktan, Penyuluh dan Penyelia Mitra Tani (PMT); 3) memberdayakan kelembagaan petani dan ekonomi perdesaan untuk pengembangan kegiatan usaha agribisnis; dan 4) meningkatkan fungsi kelembagaan ekonomi petani menjadi jejaring atau mitra lembaga keuangan dalam rangka akses ke permodalan (Dirjen Prasarana dan Sarana Pertanian, 2015).

Sasaran PUAP sebagai berikut: 1) berkembangnya usaha agribisnis di desa terutama desa miskin sesuai dengan potensi pertanian desa; 2) berkembangnya Gapoktan yang dimiliki dan dikelola oleh petani untuk menjadi kelembagaan ekonomi; 3) meningkatnya kesejahteraan rumah tangga tani miskin, petani/peternak (pemilik dan/atau penggarap) skala kecil, buruh tani; dan 4) berkembangnya usaha agribisnis petani yang mempunyai siklus usaha (Dirjen Prasarana dan Sarana Pertanian, 2015).

Indikator Keberhasilan PUAP meliputi indikator keberhasilan output antara lain: 1) tersalurkannya dana Bantuan Langsung Masyarakat (BLM) PUAP 2015 kepada petani, buruh tani dan rumah tangga tani miskin anggota Gapoktan sebagai modal untuk melakukan usaha produktif pertanian; dan 2) terlaksananya fasilitasi penguatan kapasitas dan kemampuan sumber daya manusia pengelola Gapoktan, Penyuluh dan PMT. Indikator keberhasilan outcome antara lain: 1) meningkatnya kemampuan Gapoktan dalam memfasilitasi dan mengelola bantuan modal usaha untuk petani anggota baik petani pemilik penggarap, petani penggarap, buruh tani maupun rumah tangga tani; 2) meningkatnya jumlah petani, buruh tani dan rumah tangga tani yang mendapatkan bantuan modal usaha; dan 3) meningkatnya aktivitas kegiatan usaha agribisnis (hulu, budidaya dan hilir) di perdesaan. Sedangkan Indikator benefit dan Impact antara lain: 1) berkembangnya usaha agribisnis di perdesaan; 2) berfungsinya Gapoktan sebagai lembaga ekonomi petani di perdesaan yang dimiliki dan dikelola oleh petani; dan 3) berkurangnya jumlah petani miskin dan pengangguran di perdesaan (Dirjen Prasarana dan Sarana Pertanian, 2015).

Dengan demikian, peran PUAP merupakan fungsi dalam meningkatkan kesejahteraan ekonomi petani, dan untuk melaksanakan perananya tersebut, aktor pelaksana PUAP harus melaksanakan fungsinya yang merupakan tugas atau pekerjaan yang harus dilaksanakan.

\subsection{Konsep Kesejahteraan}

Brudeseth (2015: 191) menyatakan kesejahteraan sebagai kualitas kepuasan hidup yang bertujuan untuk mengukur posisi anggota masyarakat dalam membangun 
keseimbangan hidup mencakup antara lain, (a) kesejahteraan materi, (b) kesejahteraan bermasyarakat, (c) kesejahteraan emosi, (d) keamanan.

Dalam penelitian ini tingkat kesejahteraan difokuskan pada kesejahteraan rumah tangga petani yang menerima dana PUAP melalui indikator produktivitas, pendapatan petani, dan kemampuan dalam berorganisasi.

\subsection{Kerangka Pemikiran}

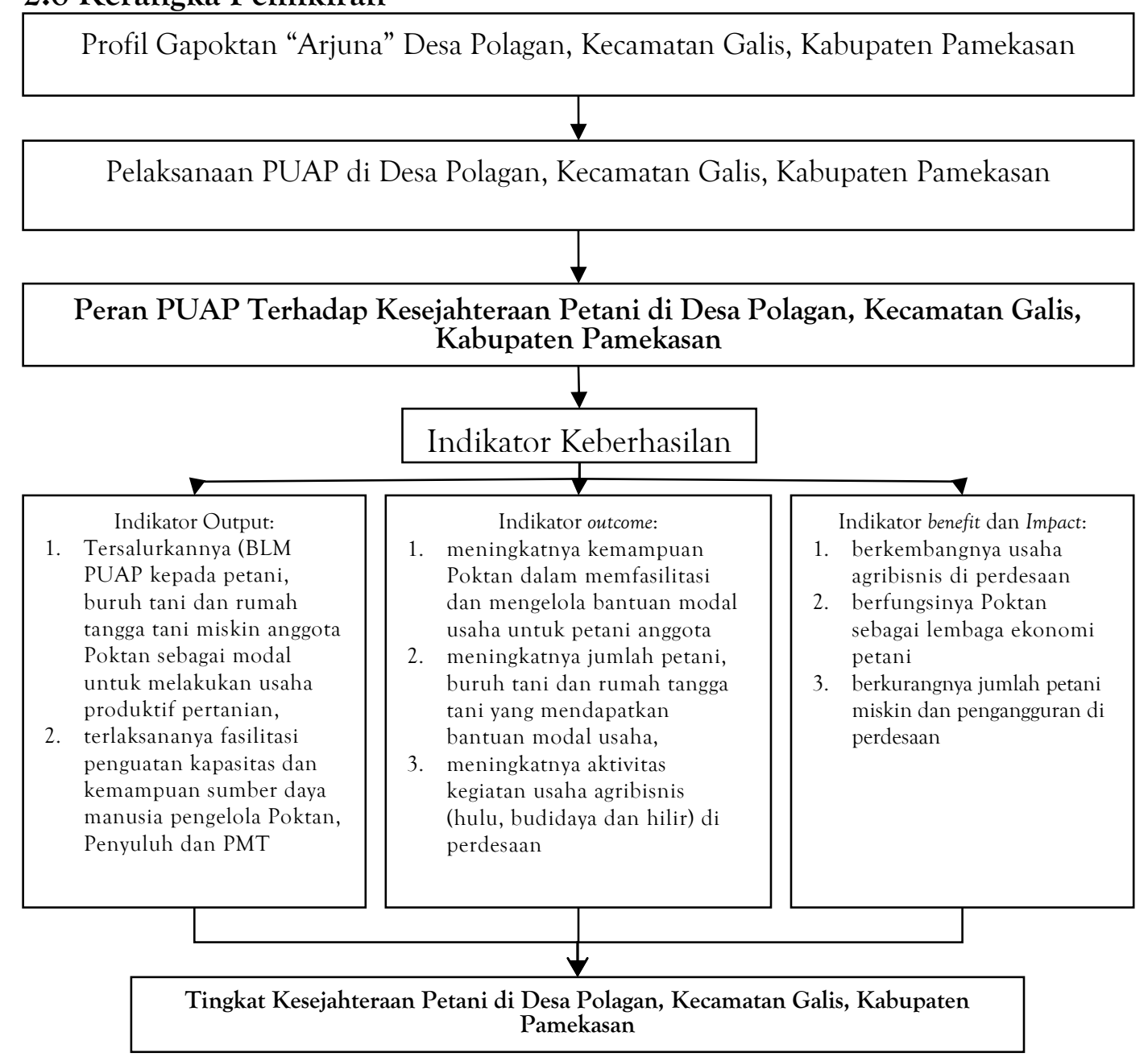

\section{METODE PENELITIAN}

Pendekatan penelitian ini adalah kualitatif deskriptif, bertujuan untuk mendapatkan informasi secara lebih mendalam dan komperhensif mengenai peran PUAP di Gapoktan "Arjuna” ini dapat meningkatkan kesejahteraan petani atau justru menambah beban petani apabila ada kegagalan. Jenis dan sumber data dalam penelitian ini adalah data primer, yakni menggunakan data hasil wawancara dengan informan Gapoktan di Desa Polagan, Kecamatan Galis, Kabupaten Pamekasan dan data sekunder berupa jurnal-jurnal atau penelitian terdahulu dan data profil Gapoktan di Desa Polagan, Kecamatan Galis, Kabupaten Pamekasan serta data lainnya yang mendukung penelitian. Penelitian ini menggunakan teknik pengumpulan data berupa wawancara, observasi dan dokumentasi. Objek dalam penelitian ini adalah kelompok tani Gapoktan "Arjuna” Desa Polagan, Kecamatan Galis, Kabupaten Pamekasan yang 
mendapatkan BLM PUAP. Subjek penelitian ini adalah informan atau narasumber yang menjadi sumber data. Teknik pemilihan informan dalam penelitian ini menggunakan snowball sampling atau chain sampling, yakni pemilihan informan kedua berdasarkan informasi dari informan pertama, informan ketiga berdasarkan rekomendasi informan kedua dan seterusnya. Metode ini digunakan karena menggunakan wawancara mendalam. Metode analisis data yang digunakan dalam penelitian ini adalah model analisis deskriptif.

\section{HASIL DAN PEMBAHASAN}

\subsection{Pelaksanaan PUAP di Desa Polagan, Kecamatan Galis, Kabupaten Pamekasan}

Desa Polagan, Kecamatan Galis, Kabupaten Pamekasan menerima bantuan PUAP pada Bulan 9 tahun 2009. Saat ini terdapat 8 poktan yang mendapatkan pinjaman dana dari PUAP. Pinjaman modal tersebut digunakan oleh para petani untuk menambah modal bagi berbagai kegiatan usahatani seperti: usahatani padi, jagung, tembakau, dan hortikultura. Dana bantuan PUAP diterima oleh Gapoktan "Arjuna pada bulan 9 tahun 2009 sebesar 100 juta. Dana tersebut disalurkan kepada masingmasing poktan yang ada 8 Poktan tersaji dalam Tabel berikut:

Tabel 1

Penyaluran Dana PUAP Gapoktan “Arjuna”

\begin{tabular}{|c|c|c|c|c|c|}
\hline No & Nama Poktan & Pinjaman ( $\mathrm{Rp})$ & Jasa 6\% (Rp) & Jumlah (Rp) & $\begin{array}{c}\text { Satuan Poktan } \\
(\mathrm{Rp})\end{array}$ \\
\hline 1 & Dewi Ratih & 13.150.000,- & 800.000,- & 13.950.000,- & $250.000,-$ \\
\hline 2 & Udang Galah & $13.150 .000,-$ & 800.000 & 13.950.000,- & 250.000 \\
\hline 3 & Sri Kuning & 13.150.000,- & 800.000 & 13.950.000,- & 250.000 \\
\hline 4 & Semeru & 13.150.000,- & 800.000,- & 13.950.000,- & 250.000,- \\
\hline 5 & Jaya Makmur & 13.150.000,- & 800.000 & 13.950.000,- & $250.000,-$ \\
\hline 6 & Seratus Malam & 13.150.000,- & 800.000,- & 13.950.000,- & 250.000 \\
\hline 7 & Sumber Makmur & 13.150.000,- & 800.000, & 13.950.000,- & $250.000,-$ \\
\hline 8 & Segara Jaya & 13.150.000,- & 800.000 & 13.950.000,- & 250.000 \\
\hline \multicolumn{2}{|r|}{ Jumlah } & 105.200.000, & 6.400.000,- & 111.600.000,- & 2.000.000, \\
\hline
\end{tabular}

Sumber: Data Laporan Gapoktan "Arjuna” (2011)

Berdasarkan tabel 1 menunjukkan bahwa dana tersalurkan secara merata kepada seluruh Poktan yang tergabung dalam Gapoktan "Arjuna”. Tempo peminjaman selama 6 bulan dengan bunga pinjaman sebesar 6\% dari setiap gapoktan diperoleh jumlah total jasa PUAP selama 6 bulan dari 8 Poktan adalah Rp. 6.400.000,-. Dana tersebut dialokasikan untuk modal sebesar Rp. 1.920 .000 (30\%), administrasi lain-lain sebesar Rp. 560.000 (8,75\%), pengelola dan pendamping sebesar Rp. 1.920 .000 (30\%) , dan kembali ke Poktan sebesar Rp. 2.000 .000 (31,25\%) (Laporan Gapktan Arjuna, 2011).

Penyaluran dana PUAP tersebut dapat digunakan sebaga perangsang modal bagi petani sehingga meringankan beban petani untuk mengembangkan usahataninya. Seperti yang disampaikan Bapak Moh Faqih, selaku Ketua Gapoktan "Arjuna”:

"...setelah ada bantuan modal usaha tani PUAP ini jadi bisa meringankan meskipun tidak 100\% modal tersebut mencukupi cuma itu termasuk perangsang modal usaha tani kan" (Hasil Wawancara, Moh Faqih, selaku Ketua Gapoktan “Arjuna”, 20 Desember 2019). 
Adapun Untuk mendapatkan pinjaman dana dari Program Usaha Agribisnis Pedesaan (PUAP) para petani harus memenuhi persyaratan yang telah ditentukan dan disepakati bersama oleh para petani dan pengurus gapoktan. Persyaratan yang harus dipenuhi para guna mengajukan pinjaman modal adalah sebagai berikut: harus menjadi anggota gapoktan, harus memenuhi simpanan pokok, harus memenuhi simpanan wajib, dan harus mematuhi peraturan yang telah disepakati bersama oleh seluruh anggota.

Pelaksanaan PUAP bertujuan memberikan bantuan modal usaha untuk gapoktan dalam menumbuhkembangkan usaha tani sesuai dengan potensi pertanian desa sasaran. Seperti yang telah diungkapkan oleh Bapak Moh. Faqih selaku Ketua Gapoktan sebagai berikut:

"Alhamdulillah lancar dan aktif untuk melakukan pertemuan, apalagi setelah ada bantuan modal usaha tani PUAP ini jadi bisa meringankan meskipun tidak 100\% modal tersebut mencukupi cuma itu termasuk perangsang modal usaha tani kan" (Hasil Wawancara, Moh Faqih, selaku Ketua Gapoktan "Arjuna", 20 Desember 2019).

Dari pemaparan beberapa informan di atas, dapat diketahui bahwa pelaksanaan program PUAP masih kebanyakan digunakan untuk simpan pinjam dengan peminjaman pertama maksimal sebesar Rp. 13.150.000,00 masing-masing Poktan dan Rp. 500.000,00 bagi anggota Poktan. Di desa Polagan jika Poktan maupun petani anggota poktan peminjam mengembalikan pinjamannya disiplin sesuai waktu yang ditentukan, maka jika nanti akan mengajukan pinjaman lagi boleh menambah jumlah pinjamannya dan seterusnya. Mayoritas tempo peminjaman selama 6 bulan dengan bunga pinjaman sebesar $6 \%$ dari setiap gapoktan. Setiap bulan $1 \%$. Sementara anggota poktan sebesar 10\% (sesuai kesepakatan). Untuk persyaratan pengajuan harus sudah menjadi anggota kelompok tani, fotokopi KTP, dan fotokopi Kartu Keluarga (KK). Para petani sangat diuntungkan sekali dengan adanya program PUAP tersebut. Dengan adanya bantuan pinjaman modal dari program PUAP, petani bisa memaksimalkan proses usaha taninya dan meningkatkan keterampilan dan pengetahuan.

Program PUAP tidak hanya berfokus pada pemberian pinjaman dana namun meningkatkan kemandirian Gapoktan, yang pada akhirnya menyalurkan kemandirian kepada seluruh anggota sampai pada petani anggota. Pendampingan dan penyuluhan merupakan salah satu faktor penting peran PUAP dalam meningkatkan kesejahteraan petani, seperti yang disampaikan Widodo Diana Dewi selaku Penyuluh Pendamping di Gapoktan Arjuna Desa Polagan bahwa anggota Gapoktan didampingi untuk membuat RKA, RKU, RKB, sehingga dapat membantu anggota Gapoktan untuk memperoleh informasi tentang pasar:

"Gini, gapoktan itu harus mandiri jadi ada seksi seksinya yang harus tahu berapa sekarang harga produksi padi, dan lain lain. Dan itu sudah terbentuk dan harus terbentuk. Misal ada seksi pemasaran, saprodi, kan pasti sudah ada bagian masing-masing. Dan juga kita dipertemuan, misal saya diundang kan, ya disana juga kita bisa berbagi informasi tentang apapun, kaitannya dengan pasar, soal pupuk, dan lain-lain” Widodo Diana Dewi, selaku Penyuluh Pendamping, 6 Januari 2020). 
Dari pemaparan beberapa informan diatas, dapat diketahui bahwa program PUAP juga dapat memberikan pemberdayaan pada petani, meskipun tidak optimal namun tetap meringankan beban petani. Hal ini karena kemampuan pengurus Poktan masih rendah karena keterbatasan kemampuan manajemen organisasi. Sebagian besar petani tidak sanggup mengemban pengurus Poktan. Seperti yang disampaikan Widodo Diana Dewi, selaku Penyuluh Pendamping:

"Biasanya ada yang tidak sanggup menjadi ketua, 'saya tidak sanggup bu' ya akhirnya melakukan pemilihan lagi dibalai desa" (Hasil wawancara, Widodo Diana Dewi, selaku Penyuluh Pendamping, 6 Januari 2020).

Atas uraian diatas dapat dikatakan bahwa pada dasarnya program PUAP tidak hanya berfokus pada pemberian pinjaman dana namun meningkatkan kemandirian Gapoktan, yang pada akhirnya menyalurkan kemandirian kepada seluruh anggota sampai pada petani anggota. Pendampingan dan penyuluhan merupakan salah satu faktor penting peran PUAP dalam meningkatkan kesejahteraan petani. Pemberdayaan yang dimaksud adalah memberi "daya" bukan "kekuasaan" daripada " pemberdayaan" itu sendiri. Gapoktan merupakan kelembagaan tani pelaksana PUAP untuk penyaluran bantuan modal usaha bagi anggota. Untuk mencapai hasil yang maksimal dalam pelaksanaan PUAP, Gapoktan didampingi oleh Tenaga Pendamping PUAP (Penyuluh dan Penyelia Mitra Tani) (Dirjen Prasarana dan Sarana Pertanian, 2015).

Program BLM ini diarahkan untuk memberdayakan masyarakat yang mencakup bantuan modal untuk pengembangan kegiatan sosial ekonomi produktif; bantuan sarana dan prasarana dasar yang mendukung kegiatan sosial ekonomi; bantuan pengembangan sumberdaya manusia untuk mendukung penguatan kegiatan sosial ekonomi; bantuan penguatan kelembagaan untuk mendukung pengembangan proses hasil-hasil kegiatan sosial ekonomi secara berkelanjutan melalui penguatan kelompok masyarakat dan unit pengelola keuangan; dan bantuan pengembangan sistem pelaporan untuk mendukung pelestarian hasil-hasil kegiatan sosial ekonomi produktif (Sumodiningrat, 2001).

\subsection{Tingkat Kesejahteraan Petani Di Desa Polagan, Kecamatan Galis, Kabupaten Pamekasan}

Tingkat Kesejahteraan secara umum di Desa Polagan masih rendah karena Desa Polagan termasuk desa kedua setelah Desa Konang mengenai banyaknya Surat Keterangan Miskin (SKM) Yang Dikeluarkan Desa di Kecamatan Galis 2016-2018, yaitu sebanyak 258 SKM dari 1335 SKM (19,32\%) (Kecamatan Galis Dalam Angka, 2019). Mengingat sebagian besar masyarakat Polagan adalah petani maka dapat dikatakan bahwa tingkat kesejahteraan petani masih rendah.

Pendapatan petani, khususnya anggota Poktan juga masih variatif. Hasil wawancara dengan anggota Poktan diperoleh data berikut: 
Tabel 2

Pendapatan Petani Anggota Poktan Gapoktan “Arjuna”

\begin{tabular}{|c|c|c|c|c|c|c|}
\hline $\begin{array}{l}\mathrm{N} \\
\mathrm{o}\end{array}$ & Petani & $\begin{array}{l}\text { Luas } \\
\text { Lahan }\end{array}$ & Pendapatan & Komoditi & Biaya Produksi & $\begin{array}{l}\text { Biaya tenaga } \\
\text { kerja }\end{array}$ \\
\hline \multirow[t]{2}{*}{1.} & \multirow[t]{2}{*}{ Astro } & \multirow[t]{2}{*}{$2500 \mathrm{~m} 2$} & \multirow[t]{2}{*}{$\begin{array}{l}7 \quad \text { juta/ } \\
\text { panen }\end{array}$} & Padi & $\begin{array}{l}2 \text { juta, dengan rincian: } \\
\quad-\quad \text { Pengolahan tanah }= \\
\text { Rp. } 500.000 \\
\quad-\quad \text { Pembelian bibit }=\text { Rp. } \\
\text { 200.000 } \\
\quad \text { Penanaman }=\mathrm{Rp} . \\
500.000\end{array}$ & $\begin{array}{l}8 \text { orang@ } @ \text { Rp. } \\
50.000=\mathrm{Rp} . \\
400.000\end{array}$ \\
\hline & & & & Tembakau & $\begin{array}{l}5 \text { juta dengan rincian: } \\
-\quad 6000 \text { pohon tembakau } \\
\text { yang ditanam } \\
-\quad \text { Pengolahan lahan }= \\
\text { Rp. } 800.000 \\
-\quad \text { Pembelian bibit } \\
\text { dimana per } 1000 \text { pohon } \\
\text { harganya Rp. } 20.000 . \text { Jadi } \\
\text { untuk bibit } 120.000\end{array}$ & $\begin{array}{l}5 \text { orang@Rp. } \\
50.000=\mathrm{Rp} . \\
250.000\end{array}$ \\
\hline \multirow[t]{3}{*}{2.} & \multirow[t]{3}{*}{ Busri } & \multirow[t]{3}{*}{$1 / 2$ hektar } & \multirow[t]{3}{*}{$\begin{array}{l}\text { 10juta/ } \\
\text { panen }\end{array}$} & Padi & $\begin{array}{l}3 \text { juta, dengan rincian: } \\
-\quad \text { Pengolahan tanah }= \\
\text { Rp. } 1,5 \text { juta } \\
\quad-\quad \text { Pembelian bibit }=\text { Rp. } \\
210.000\end{array}$ & $\begin{array}{l}10 \text { orang @ Rp. } \\
50.000=\mathrm{Rp} . \\
500.000\end{array}$ \\
\hline & & & & Tembakau & $\begin{array}{l}6 \text { juta, dengan rincian: } \\
-\quad 8000 \text { pohon tembakau } \\
\text { yang ditanam } \\
\text { - } \quad \text { Pupuk } 6 \text { kwintal } \\
\text { Rp. } 600.000 \\
\text { - } \quad \text { Perairan proses tanam } \\
\text { - panen }=\text { Rp. } 125.000\end{array}$ & $\begin{array}{l}10 \text { orang @ Rp. } \\
50.000=\mathrm{Rp} . \\
500.000\end{array}$ \\
\hline & & & & Jagung & $\begin{array}{l}2 \text { juta, dengan rincian untuk } \\
\text { biaya pembelian bibit, } \\
\text { pengolahan lahan, dan } \\
\text { pengairan }\end{array}$ & \\
\hline \multirow[t]{2}{*}{3.} & \multirow[t]{2}{*}{ Sukardi } & \multirow[t]{2}{*}{$4000 \mathrm{~m} 2$} & \multirow{2}{*}{$\begin{array}{l}15 \mathrm{Juta} / \\
\text { panen }\end{array}$} & Padi & 2,5 Juta & \\
\hline & & & & Bawang Merah & 7 Juta & \\
\hline
\end{tabular}

Sumber: hasil data lapangan, diolah

\subsection{Peran PUAP Terhadap Kesejahteraan Petani Di Desa Polagan, Kecamatan Galis, Kabupaten Pamekasan}

Penyaluran dana Bantuan Langsung Masyarakat (BLM) PUAP ditujukan kepada petani, buruh tani dan rumah tangga tani miskin anggota Gapoktan sebagai modal untuk melakukan usaha produktif pertanian. Program PUAP di Di Desa Polagan, Kecamatan Galis, Kabupaten Pamekasan disalurkan kepada petani padi, jagung, dan tembakau yang tergabung dalam Gapoktan "Arjuna” dalam bentuk simpan pinjam. Pemberian pinjaman diharapkan dapat dikelola dengan baik agar kemiskinan di pedesaan dapat berkurang signifikan, salah satunya dengan berbagai kegiatan pemberdayaan petani seperti yang disampaikan oleh Bapak Faqih selaku ketua Gapoktan "Arjuna" dengan menggunakan inovasi pola tanam 3 kali dengan penanaman padi, tembakau, jagung dikombinasi dengan tanaman holtikultura, bawang, tomat, dan lain-lain. 
Berdasarkan data laporan dan paparan informan di atas diketahui bahwa secara penyaluran dana PUAP sudah baik, sehingga dapat dimanfaatkan oleh petani untuk modal mengembangkan usaha tani berupa biaya beli benih, pupuk, dan perawatan tanaman seperti obat-obatan. Terbukti dari beberapa petani merasa adanya dana PUAP dapat meningkatkan pendapatan petani, seperti yang dialami oleh Bapak Busri selaku petani pengguna dana program PUAP di gapoktan "Arjuna" dapat penghasilan perbulan rata-rata $10 \mathrm{juta} /$ musim panen, Bapak Astro selaku petani pengguna dana program PUAP di gapoktan "Arjuna" dapat penghasilan perbulan rata-rata 7 juta/musim panen, dan Bapak Sukardi selaku petani pengguna dana program PUAP di gapoktan "Arjuna” dapat penghasilan perbulan rata-rata $15 \mathrm{juta} / \mathrm{musim}$ panen. Hal ini sejalan dengan salah tujuan PUAP bahwa program PUAP dapat mengurangi kemiskinan dan pengangguran melalui penumbuhan dan pengembangan kegiatan usaha agribisnis di perdesaan sesuai dengan potensi wilayah.

Penelitian Suadi dkk. (2012) menunjukkan bahwa pelaksanaan program PUAP di daerah penelitian memberikan peran penting untuk kemajuan pembangunan pertanian terutama bantuan modal kepada petani, bimbingan dan pelatihan bagi petani yang belum terampil. Namun model yang dikembangkan di daerah penelitian periode 2009-2010 masih belum mampu mengentaskan kemiskinan penduduk, dan pengangguran. Pelaksanaan Program PUAP di daerah penelitian dapat meningkatkan kesempatan kerja dan penghasilan anggota kelompok, namun belum mampu mengembangkan lembaga Keuangan Mikro dan Jejaring Mitra Kerja petani. Hasil analisis menunjukkan bahwa variabel program PUAP melalui manajemen sumberdaya gapoktan berpengaruh positif sangat nyata terhadap peningkatan kesejahteraan petani. Hal ini mengindikasikan bahwa program PUAP sangat berperan terhadap peningkatan kesejahteraan petani namun perlu dikelola secara intensif dan profesional berbasis sumberdaya lokal.

Program PUAP tidak hanya berfokus pada pemberian pinjaman dana namun meningkatkan kemandirian Gapoktan, yang pada akhirnya menyalurkan kemandirian kepada seluruh anggota sampai pada petani anggota. Pendampingan dan penyuluhan merupakan salah satu faktor penting peran PUAP dalam meningkatkan kesejahteraan petani. Gapoktan merupakan kelembagaan tani pelaksana PUAP untuk penyaluran bantuan modal usaha bagi anggota. Untuk mencapai hasil yang maksimal dalam pelaksanaan PUAP, Gapoktan didampingi oleh Tenaga Pendamping PUAP (Penyuluh dan Penyelia Mitra Tani) (Dirjen Prasarana dan Sarana Pertanian, 2015).

Berdasarkan hasil penelitian ditemukan bahwa pengurus Gapoktan sudah memiliki AD/ART dan program PUAP, sehingga poktan dan anggotanya dapat berkembang dengan baik sesuai tujuan program PUAP. Fakta di lapangan ternyata kemampuan pengurus Poktan masih rendah karena keterbatasan kemampuan manajemen organisasi. Sebagian besar petani tidak sanggup mengemban pengurus Poktan. Hal ini menunjukkan bahwa SDM pengurus Gapoktan masih rendah sehingga dalam pengelolaan kurang optimal. Hal ini karena dipengaruhi oleh umur dan tingkat pendidikan, sehingga berpengaruh pada masalah pembukuan, dan berdampak pada pengelolaan dana PUAP itu sendiri. 
Penelitian Darwis (2014) menunjukkan pemberdayaan pengembangan usaha agribisnis pedesaan berjalan dengan baik dengan indikator keberhasilan kerja sesuai pada tahapan proses pemberdayaan $80 \%$ para informan dapat mengembangkan usahanya dengan baik.

Berdasarkan hasil wawancara dengan Bapak Faqih, selaku ketua Gapoktan dan Bapak Suadi, selaku Bendahara Gapoktan Arjuna diketahui bahwa terdapat peningkatan jumlah petani, buruh tani dan rumah tangga tani yang mendapatkan bantuan modal usaha dari program PUAP, namun peningkatan tidak signifikan. Hal ini dapat terjadi karena kurangnya kesadaran masyarakat dalam mengembalikan dana PUAP dan kemampuan pengurus Gapoktan yang rendah.

Berbagai macam peluang dan hambatan timbul dalam usaha tani sesuai dengan lingkungan sosial ekonomi setempat. Oleh karena itu diperlukan pengembangan kelompok tani ke dalam suatu organisasi yang jauh lebih besar. Beberapa kelompok tani bergabung ke dalam gabungan kelompok tani (Gapoktan). Penggabungan dalam Gapoktan terutama dilakukan oleh kelompok tani yang berada dalam satu wilayah administrasi Pemerintahan untuk menggalang kepentingan bersama secara kooperatif. Wilayah kerja Gapoktan sedapat mungkin di wilayah administrasi desa/kecamatan (Anonimus, 2007 : 4).

Berdasarkan wawancara dengan para informan menunjukkan bahwa aktivitas kegiatan usaha agribisnis (hulu, budidaya dan hilir) di desa Polagan semakin meningkat setelah menerima bantuan PUAP. Hal ini sesuai dengan Indikator keberhasilan outcome antara lain: 1) meningkatnya kemampuan Gapoktan dalam memfasilitasi dan mengelola bantuan modal usaha untuk petani anggota baik petani pemilik penggarap, petani penggarap, buruh tani maupun rumah tangga tani; 2) meningkatnya jumlah petani, buruh tani dan rumah tangga tani yang mendapatkan bantuan modal usaha; dan 3) meningkatnya aktivitas kegiatan usaha agribisnis (hulu, budidaya dan hilir) di perdesaan (Direktorat Jenderal Prasarana dan Sarana Pertanian, 2015).

Berdasarkan hasil wawancara dengan Bapak Moh. Faqih selaku Ketua Gapoktan menjelaskan bahwa ada perbedaan usaha agribisnis sebelum dan setelah adanya PUAP. Hal ini dibuktikan dengan nilai jual yang lebih tinggi, variasi tanam dengan alternatif pola tanam, dan lain-lain.

Berdasarkan seluruh uraian di atas dapat disimpulkan bahwa peran PUAP sudah baik dalam meningkatkan kesejahteraan petani Di Desa Polagan, Kecamatan Galis, Kabupaten Pamekasan, namun kuang optimal. Hal ini karena tingkat kesadaran anggota masih rendah dalam hal pengembalian pinjaman dan SDM pengurus Gapoktan masih rendah sehingga dalam pengelolaan kurang optimal. Hal ini karena dipengaruhi oleh umur dan tingkat pendidikan, sehingga berpengaruh pada masalah pembukuan, dan berdampak pada pengelolaan dana PUAP itu sendiri.

Penelitian Hermawan dan Hendayana, (2015) menunjukkan adanya Peran BLM PUAP di Kabupaten Kolaka Provinsi Sulawesi Tenggara mampu meningkatkan produktivitas, nilai tambah, daya saing dan ekspor produk pertanian, bahkan pada kegiatan usaha tani yang dilakukan petani mampu memberikan pendapatan yang lebih menguntungkan. Kesejahteraan merupakan barometer penting dalam mengetahui 
kualitas hidup masyarakat. Pemenuhan kebutuhan dalam pengembangan usahatani yang sesuai dengan kondisi yang dihadapi petani dapat menjadi tolok ukur bahwa petani memiliki tingkat kesejahteraan yang baik.

Poktan sebagai lembaga ekonomi petani di Desa Polagan sudah berfungsi dengan baik. Ini dapat terjadi sebab adanya pertemuan rutin yang dilakukan Gapoktan "Arjuna" sehingga menambah pengetahuan bagi petani karena ada pertukaran informasi dan berbagi pengalaman dari masing-masing Poktan. Selain itu, Lembaga Keuangan Mikro Agribisnis (LKM-A) sebagai salah satu unit usaha otonom yang didirikan dan dimiliki oleh Gapoktan penerima dana BLM-PUAP dalam bentuk LKM guna memecahkan masalah/kendala akses untuk mendapatkan pelayanan keuangan berperan dengan baik karena dapat memberikan pembinaan bagi petani untuk pengelolaan uang modal usaha.

Hasil wawancara menunjukkan bahwa program PUAP dapat meringankan beban petani dalam hal pengembangan usahatani, meskipun tidak signifikan. Petani dapat terbantu terfasilitasi pembelian pupuk, mengetahui tanaman yang potensial untuk ditanam, adanya pemerataan informasi sehingga terjadi inovasi pola tanam.

Berdasarkan temuan penelitian menunjukkan bahwa program PUAP berperan mengurangi kemiskinan petani, meskipun tidak signifikan. Program PUAP tersebut membuat petani semakin mandiri karena meningkatkan pencapaian kemampuan pengetahuan dan ketrampilan, sehingga nilai jual hasil pertanian semakin tinggi. Menurut Widjajanti (2011) tujuan dari adanya pemberdayaan masyarakat yaitu untuk menjadikan masyarakat bersikap mandiri sehingga dapat meningkatkan kesejahteraan hidup dalam keluarganya serta dapat mengoptimalkan potensi yang dimilikinya. Hal ini dilihat dari indikator keberhasilan program PUAP menunjukkan secara output antara lain: 1) dana Bantuan Langsung Masyarakat (BLM) PUAP kepada petani, buruh tani dan rumah tangga tani miskin anggota Gapoktan sebagai modal untuk melakukan usaha produktif pertanian tersalurkan dengan baik meskipun pinjaman modal dinialimasih kecil bagi petani; dan 2) fasilitasi penguatan kapasitas dan kemampuan sumber daya manusia pengelola Gapoktan, Penyuluh dan PMT terlaksana dengan baik namun kurang optimal karena peran pengelola Gapoktan masih banyak yang pengurus yang kurang mampu dalam manajemen organsiasi, Penyuluh dan PMT mengalami overload dalam menangani desa penerima bantuan PUAP. Secara outcome antara lain: 1) kemampuan Gapoktan dalam memfasilitasi dan mengelola bantuan modal usaha untuk petani anggota baik petani pemilik penggarap, petani penggarap, buruh tani maupun rumah tangga tani sudah baik karena sudah memiliki AD/ART dan program PUAP, sehingga poktan dan anggotanya dapat berkembang dengan baik sesuai tujuan program PUAP, namun terkendala kemampuan pengurus Poktan masih rendah karena keterbatasan kemampuan manajemen organisasi. Sebagian besar petani tidak sanggup mengemban sebagai pengurus Poktan; 2) jumlah petani, buruh tani dan rumah tangga tani yang mendapatkan bantuan modal usaha sudah meningkat namun tidak signifikan; 3) aktivitas kegiatan usaha agribisnis (hulu, budidaya dan hilir) di desa Polagan semakin meningkat setelah menerima bantuan PUAP. Secara benefit dan Impact antara lain: 1) usaha agribisnis di Desa Polagan berkembang dengan baik. Hal 
ini dibuktikan dengan nilai jual yang lebih tinggi, variasi tanam dengan alternatif pola tanam, dan lain-lain; 2) Poktan sebagai lembaga ekonomi petani di Desa Polagan sudah berfungsi dengan baik karena didukung Lembaga Keuangan Mikro Agribisnis (LKMA) yang berjalan dengan baik; dan 3) jumlah petani miskin dan pengangguran di Desa Poalgan semakin berkurang namun tidak signifikan.

Berdasarkan seluruh uraian di atas peran PUAP terhadap kesejahteraan petani kurang maksimal baik dalam hal penyaluran pendanaan maupun pemberdayaan. Dari sisi penyaluran dana yang kurang maksimal adalah adanya kesenjangan antara kebutuhan petani anggota Poktan dengan dana pinjaman anggota kepada Poktan. Data menunjukkan bahwa kebutuhan petani untuk mempercepat komoditi sebagian besar menambah dana dari modal sendiri, yang diperoleh dari keuntungan hasil panen sebelumnya. Seperti yang dialami Bapak Astro, dengan memiliki luas lahan $2500 \mathrm{~m} 2$, ditanami komoditi padi dan tembakau membutuhkan biaya total sebesar Rp.7 juta, sementara pendapatan kotor kembali modal yaitu Rp.7 juta. Adapun dana BLM PUAP dari pengurus Poktan hanya dibatasi Rp. 500.000,00 per anggota Poktan.

Hal serupa dialami Bapak Busri, dengan memiliki luas lahan $1 / 2$ hektar, ditanami komoditi padi, tembakau, dan jagung membutuhkan biaya produksi total sebesar Rp.11 juta, sementara pendapatan kotor Rp.10 juta. Adapun dana BLM PUAP dari pengurus Poktan hanya dibatasi Rp. 500.000,00 per anggota Poktan. Hasil berbeda dialami Bapak Sukardi, dengan memiliki luas lahan $4000 \mathrm{~m} 2$, ditanami komoditi padi dan abwang merah membutuhkan biaya total sebesar 9,5 juta, namun mendapatkan pendapatan kotor sebesar Rp.15 juta.

Persoalan utama dari ketiga contoh anggota di atas adalah biaya produksi salah satunya biaya produksi tenaga kerja. Hal ini dikarenakan proses pelaksanaan kegiatan usahatani padi mulai dari persiapan lahan hingga pemanenan membutuhkan tenaga kerja dengan curahan waktu kerja yang relatif banyak. Kegiatan tersebut meliputi pengolahan lahan, pemeliharaan tanaman padi seperti pemupukan, penyiangan, pemberantasan hama dan penyakit hingga pada pemanenan. Tujuannya adalah mempercepat panen.

Persoalan lain adalah diperlukan peralatan pendukung untuk mendukung produksi komoditi. Umumnya alat-alat yang sering digunakan oleh petani adalah cangkul, sabit, parang, semprotan dan lain sebagainya. Semua alat-alat pertanian tersebut memiliki nilai penyusutan yakni totalnya sebesar $\mathrm{Rp} 182.071,00$.Total ratarata pendapatan usahatani padi petani anggota poktan dengan luas lahan 1 hektar sebelum menerima PUAP berjumlah Rp8.153.370,00 dan setelah menerima PUAP total rata-rata pendapatan petani anggota Poktan mengalami peningkatan menjadi sebesar Rp11.041.206,00 dengan persentase perubahan meningkat sebesar 26,16 persen. Peningkatan pendapatan usahatani padi merupakan salah satu tujuan dari dilaksanakannya program PUAP, dengan harapan melalui peningkatan pendapatan usahatani maka dapat membantu peningkatan kesejahteraan keluarga petani. Namun persentase tersebut belum cukup untuk menunjukkan bahwa terdapat perbedaan secara nyata pada tingkat pendapatan sebelum dan setelah memanfaatkan dana PUAP. 
Dengan demikian dapat dikatakan bahwa peran PUAP terhadap tingkat kesejahteraan petani di Desa Polagan belum memberikan perbedaan yang signifikan. Hal ini karena dana BLM PUAP hanya menjadi stimulus untuk menambah modal usaha tani para anggota. Beberapa informan anggota Poktan menyatakan bahwa sebagian besar menggarap lahan miliknya sendiri, luas lahan yang dimiliki rata-rata dibawah $5000 \mathrm{~m} 2$. Tenaga kerja yang digunakan rata-rata masih keluarga. Mayoritas petani menggunakan dana BLM PUAP untuk menambah modal usahanya. Sebagian besar anggota menyatakan tidak ingin melakukan peminjaman kembali karena belum merasakan manfaat dari pinjaman tersebut.

Peran PUAP dalam pemberdayaan masyarakat petani melalui program PUAP di Gapoktan Arjuna Desa Polagan dapat dilihat dari aspek sasaran, teknik dan tujuan. Dari aspek sasaran yaitu masyarakat petani yang tergabung dalam kelembagaan Gapoktan yang berada pada desa miskin. Kelembagaan Gapoktan Arjuna Desa Polagan masih lemah karena masih adanya kesenjangan hubungan antara masyarakat petani biasa dengan kelembagaan yang berdampak pada banyaknya usaha agribisnis yang dikelola di Gapoktan tidak dapat berkembang. Dari segi teknik, Gapoktan masih belum mampu mengembangkan inovasi usaha pengolahan produk pemberi nilai tambah karena rendahnya kesadaran masyarakat petani dan kecilnya intensitas pemberian pelatihan dari tenaga pendamping. Dari aspek tujuan, sudah dapat digunakan untuk meningkatkan pengetahuan dan keterampilan masyarakat petani sehingga dapat digunakan dalam pengembangan usaha agribisnis di Gapoktan Arjuna Desa Polagan, namun tidak semua usaha tersebut dapat berkembang dengan baik sehingga masih belum mampu meningkatkan kesejahteraan anggota. Peningkatan kemampuan dan keterampilan tidak terjadi pada semua masyarakat petani anggota Gapoktan dan hanya terjadi pada masyarakat petani tertentu saja yaitu pengurus kelembagaan Gapoktan. Jenis usaha yang dapat berkembang hanya pada unit usaha simpan pinjam sehingga hanya dapat memudahkan akses petani terhadap permodalan, sedangkan untuk kontribusi peningkatan produksi dan pendapatan masih sangat kecil.

Menurut teori transformasi struktural pertumbuhan ekonomi yang disertai dengan transformasi struktural dapat dicapai dengan cara: (1) meningkatkan produktivitas setiap sektor dan (2) mengalihkan tenaga kerja dari sektor dengan produktivitas rendah ke sektor dengan produktivitas tinggi. Salah satu sektor primer di Indonesia adalah pertanian. Pertanian menjadi sektor yang penting bagi Indonesia. Indonesia merupakan negara yang sedang bertrasformasi struktural (transforming countries) dari sektor pertanian dicirikan dengan sebagian besar petani menggarap lahan yang sempit atau kurang dari 0,86 hektar. Transformasi struktural ekonomi umumnya dari pertanian tradisional ke sektor agroindustri dan sektor non-pertanian (agribisnis) yang menciptakan nilai tambah (value added) yang lebih tinggi (Susilowati dan Maulana, 2012). Dalam kasus penelitian ini belum mencapai transformasi struktural ekonomi yang diharapkan. Hal ini diduga kuat sektor pertanian mengalami perubahan struktural yang tidak seimbang. Data menunjukkan bahwa jumlah tenaga kerja di sektor pertanian pada tahun 2019 mencapai 27,33\%, namun pada saat yang sama, pangsa sektor pertanian terhadap PDB pada tahun 2019 hanya tinggal 13,45\% (Badan 
Pusat Statistik, 2020), artinya transformasi ekonomi yang ditandai dengan penurunan kontribusi sektor-sektor primer, termasuk sektor pertanian tidak diikuti oleh transformasi ketenagakerjaan.

\section{PENUTUP}

Program Pengembangan Usaha Agribisnis Perdesaan (PUAP) di Desa Polagan, Kecamatan Galis, Kabupaten Pamekasan sudah baik pelaksanaan karena proses penyaluran PUAP kepada petani sudah sesuai prosedur. Mayoritas dana program PUAP digunakan dalam bentuk simpan pinjam. Sementara Tingkat kesejahteraan petani di Desa Polagan, secara keseluruhan relatif rendah, khususnya anggota poktan dan petani secara umum. Produktivitas petani masih rendah, dan kemampuan dalam berorganisasi masih rendah. Peran Program Pengembangan Usaha Agribisnis Perdesaan (PUAP) terhadap kesejahteraan petani di Desa Polagan, Kecamatan Galis, Kabupaten Pamekasan belum memberikan perbedaan yang signifikan antara sebelum dan setelah adanya BLM PUAP. Dari aspek sasaran yaitu masyarakat petani yang tergabung dalam kelembagaan Gapoktan yang berada pada desa miskin. Kelembagaan Gapoktan Arjuna Desa Polagan masih lemah karena masih adanya kesenjangan hubungan antara masyarakat petani biasa dengan pengurus lembaga poktan yang berdampak pada banyaknya usaha agribisnis yang dikelola di Gapoktan tidak dapat berkembang. Dari segi teknik, Gapoktan masih belum mampu mengembangkan inovasi usaha pengolahan produk pemberi nilai tambah karena rendahnya kesadaran masyarakat petani dan kecilnya intensitas pemberian pelatihan dari tenaga pendamping. Dari aspek tujuan, sudah dapat digunakan untuk meningkatkan pengetahuan dan keterampilan masyarakat petani sehingga dapat digunakan dalam pengembangan usaha agribisnis di Gapoktan Arjuna Desa Polagan, namun tidak semua usaha tersebut dapat berkembang dengan baik sehingga masih belum mampu meningkatkan kesejahteraan anggota. Peningkatan kemampuan dan keterampilan tidak terjadi pada semua masyarakat petani anggota Gapoktan dan hanya terjadi pada masyarakat petani tertentu saja yaitu pengurus kelembagaan Gapoktan. Jenis usaha yang dapat berkembang hanya pada unit usaha simpan pinjam sehingga hanya dapat memudahkan akses petani terhadap permodalan, sedangkan untuk kontribusi peningkatan produksi dan pendapatan masih sangat kecil.

Rekomendasi yang diberikan adalah program PUAP pada Gabungan Kelompok Tani (Gapoktan) diharapkan dalam penyalurannya tidak hanya berupa dana pinjaman modal pertanian saja akan tetapi melalui inovasi baru lainnya. Seperti halnya penyediaan pupuk bersubsidi yang dikelola Gabungan Kelompok Tani (Gapoktan) untuk lebih memudahkan para petani dalam menjalankan usaha taninya. Sehingga penyaluran dana PUAP nantinya tidak hanya melalui bentuk pembiayaan saja, tetapi bisa berupa barang kebutuhan pertanian.

\section{DAFTAR PUSTAKA}

Aziz, A. S. (2005). Dakwah Pemberdayaan Masyarakat Paradigma Aksi Metodologi. Yogyakarta: Dakwah Pers. 
Brudeseth. (2015). A Social Workers Guide to Working In School. Adelaide: Australian Association of Social Workers.

Darwis, R. (2014). Analisis Pemberdayaan Kelompok Tani Melalui Program Pengembangan Usaha Agribisnis (PUAP) Dalam Upaya Kesejahteraan Anggota Kelompok (Studi Kasus Gabungan Kelompok Tani Desa TanjungTebat Kecamatan Bunga Mas Bengku Selatan. Bengkulu: Universitas Bengkulu.

Hermawan, d. (2015). Peran Bantuan Langsung Masyarakat Melalui PUAP terhadap Struktur Pembiayaan dan Pendapatan Usaha Tani. Jurnal Pengkajian dan Pengembangan Teknologi.

Pertanian, K. (2010). Pedoman Umum Pengembangan Usaha Agribisnis Perdesaan (PUAP). Jakarta: Kementerian Pertanian.

Pratiwi, M. (2010). Partisipasi Masyarakat Terhadap Peningkatan Pembangunan Desa. Buletin Ekonomi, 8(1), 1-8.

Prijono, O. d. (1996). Pemberdayaan: Konsep, Kebijakan dan Implementasi. Jakarta: CSIS. Romli, M. d. (2016). Transformasi Struktural : Faktor-Faktor dan Pengaruhnya Terhadap Disparitas Pendapatan di Madura. Jurnal Ekonomi dan Kebijakan Pembangunan Vol. 5, No.1.

Rostow, W. (1960). The Stagers of Economic Growth : A Non-Communist Manifesto. London: Cambridge University Press.

Suandi, d. (2012). Model Pengembangan Usaha Agribisnis Perdesaan Pada Usahatani Padi Sawah di Kecamatan Sekernan Kabupaten Muaro Jambi Provinsi Jambi. Jurnal Penelitian Universitas Jambi, Seri Humaniora, Volume 14, Nomor 2, Juli Desember 2012.

Suparjan dan Suryatno, H. (2003). Pengembangan Masyarakat Dari Pembangunan Sampai Pemberdayaan. Yogyakarta: Aditya Media.

Tambunan, T. (2013). Perekonomian Indonesia : Teori dan Temuan Empiris . Jakarta: Ghalia Indonesia.

Tri, W. (1998). Memahami Pemberdayaan Masyarakat Desa Partisipatif dalam Orientasi Pembangunan Masyarakat Desa menyongsong abad 21 Menuju Pemberdayaan Pelayanan Masyarakat. Yogyakarta: Adtya Media.

Widjajanti, K. (2011). Model Pemberdayaan Masyarakat. Jurnal Ekonomi Pembangunan, Volume 12, Nomor 1, hlm.15-27.

Yustika, A. E. (2013). Ekonomi Kelembagaan: Paradigma, Teori, dan Kebijakan. Jakarta: Erlangga.

Anonimus, 2007. Ragam Media Tanam. (http://warintek.progressio.or.id/.) Diakses tanggal 22 juni 2020

Badan Pusat Statistik, 2019. Profl Kemiskinan di Indonesia Maret 2019. Jakarta: BPS. https://www.bps.go.id/pressrelease/2019/07/15/1629/persentase-pendudukmiskin-maret-2019-sebesar-9-41-persen.html, diakses tanggal 10 Maret 2020

Badan Pusat Statistik, 2020. Struktur Produk Domestik Bruto Menurut Lapangan Usaha Kuartal III 2019. Jakarta: BPS. https://www.bps.go.id/pressrelease/2019/11/05/1622/ekonomi-indonesiatriwulan-iii-2019-tumbuh-5-02-persen.html. Diakses 30 Juli 2020 
Direktorat Jenderal Prasarana dan Sarana Pertanian, 2015. Pedoman Pengembagan Usaha Agribisnis Perdesaan TA 2015. Jakarta: Kementerian Pertanian. https://psp.pertanian.go.id/wp-content/uploads/2020/06/PedomanPengembangan-Usaha-Agribisnis-Perdesaan-TA-2015.pdf. Diakses tanggal 10 Maret 2020

Kecamatan Galis Dalam Angka 2019. https://bangkalankab.bps.go.id/publication/2019/10/18/987c85b1790a0ff42 149d367/kecamatan-burneh-dalam-angka-2019.html. Diakses tanggal 10 Maret 2020 